\title{
Hypoxic Induction of Endothelial Cell Growth Factors in Retinal Cells: Identification and Characterization of Vascular Endothelial Growth Factor (VEGF) as the Mitogen
}

\author{
David T. Shima, ${ }^{*}$ Anthony P. Adamis, ${ }^{+\neq}$Napoleone Ferrara, ${ }^{\$}$ \\ Kiang-Teck Yeo," Tet-Kin Yeo," Rapheal Allende," \\ Judah Folkman, ${ }^{\neq *}$ and Patricia A. D'Amore ${ }^{* \neq * *}$ \\ *Program in Cell and Developmental Biology, Harvard Medical \\ School, Boston, Massachusetts, U.S.A. 'Department of Ophthalmology, \\ Massachusetts Eye and Ear Infirmary, Boston, Massachusetts, U.S.A. \\ ${ }^{\ddagger}$ Department of Surgery, Children's Hospital, Boston, Massachusetts, \\ U.S.A. ${ }^{\S}$ Department of Cardiovascular Research, Genentech, Inc., S. \\ San Francisco, California, U.S.A. "Department of Pathology, Beth \\ Israel Hospital, Boston, Massachusetts, U.S.A. Departments of ${ }^{\#}$ Cell \\ Biology and ${ }^{* *}$ Pathology, Harvard Medical School, Boston, \\ Massachusetts, U.S.A.
}

\begin{abstract}
Background: New vessel growth is often associated with ischemia, and hypoxic tissue has been identified as a potential source of angiogenic factors. In particular, ischemia is associated with the development of neovascularization in a number of ocular pathologies. For this reason, we have studied the induction of endothelial cell mitogens by hypoxia in retinal cells. Materials and Methods: Human retinal pigment epithelium (hRPE) were grown under normoxic and hypoxic conditions and examined for the production of endothelial mitogens. Northern analysis, biosynthetic labeling and immunoprecipitation, and ELISA were used to assess the levels of vascular endothelial growth factor/vascular permeability factor (VEGF) and basic fibroblast growth factor (bFGF), two endothelial cell mitogens and potent angiogenic factors. Soluble receptors for VEGF were employed as competitive inhibitors to determine the contribution of the growth factor to the hypoxia-stimulated mitogen production.

Results: Following 6-24 hr of hypoxia, confluent and growing cultures of hRPE increase their levels of VEGF mRNA and protein synthesis. Biosynthetic labeling studies and RT-PCR analysis indicate that the cells secrete $\mathrm{VEGF}_{121}$ and $\mathrm{VEGF}_{165}$, the soluble forms of the
\end{abstract}

angiogenic factor. In contrast, hRPE cultured under hypoxic conditions show reduced steady-state levels of basic fibroblast growth factor (bFGF) mRNA and decreased bFGF protein synthesis. Unlike VEGF, bFGF is not found in conditioned media of hRPE following 24 $\mathrm{hr}$ of hypoxia. Using a soluble high-affinity VEGF receptor as a competitive inhibitor of VEGF, we demonstrate that a VEGF-like activity is the sole hypoxiainducible endothelial mitogen produced by cultured hRPE.

Conclusions: From this comparison we conclude that hRPE do not respond to hypoxia with a general, nonspecific increase in the overall levels of growth factors, as is seen during cell wounding responses or serum stimulation. The physiological relevance of data from this in vitro model are affirmed by separate studies in an animal model of retinal ischemia-induced ocular neovascularization ( 1 ) in which retina-derived VEGF levels have been shown to correlate spatio-temporally with the onset of angiogenesis. Taken together, these data support the hypothesis that the induction of VEGF by hypoxia mediates the rapid, initial angiogenic response to retinal ischemia.

Address correspondence and reprint requests to: Patricia A. D'Amore, Laboratory for Surgical Research, Children's Hospital, 300 Longwood Avenue, Boston, MA 02115, U.S.A. 


\section{INTRODUCTION}

Angiogenesis often occurs in a hypoxic setting. Tumors and wounds, as well as ovarian and ocular tissues, all have hypoxic regions that are spatially and temporally associated with the onset of angiogenesis (2). In recent years, it has been recognized that lower relative $\mathrm{pO}_{2}$ levels are associated with the increased expression of specific "hypoxia associated-proteins" (3-6). Hypoxia is associated with the release of angiogenic factors by macrophages (7), increased levels of mRNA for angiogenic peptides in tumors (8), and increased numbers of high-affinity receptors for angiogenic peptides on the surface of endothelial cells (9). These data are consistent with the hypothesis that hypoxia may act as a regulator of the angiogenic process.

The association of hypoxia and new vessel growth is dramatically illustrated and well documented during ocular neovascular disease. In virtually all animal models of ocular neovascularization, as well as during the course of most human neovascular pathologies, new vessel growth is preceded by the appearance of areas of nonperfused tissue, creating local ischemia. Michaelson (10), and then later Ashton (11), postulated that the areas of local nonperfusion and subsequent hypoxia were responsible for the production of angiogenic factors, which would stimulate neovascularization in order to overcome the oxygen debt. These early observations have led to the search for angiogenic factors from the eye. Of the numerous factors identified (12), none have been conclusively shown to mediate experimental or pathological ocular neovascularization.

We have used an in vitro model of human retinal pigment epithelium (hRPE) to recreate tissue hypoxia with the goal of identifying hypoxia-inducible endothelial mitogens. hRPE represent a reasonably abundant and easily cultured retinal cell type for use in the bioassay and biochemical and molecular analysis of growth factor production. Thus, these cells provide an ideal nontransformed system in which to investigate the hypoxic regulation of endothelial mitogens in retinal cells. Further, it has been suggested that disruption of normal hRPE function may lead to the production of angiogenic factors responsible for subretinal and epiretinal neovascularization $(13,14)$. hRPE in vitro synthesize a number of endothelial mitogens, including basic fibroblast growth factor (bFGF) (15), IL-8 (16), acidic fibroblast growth factor (aFGF) (17) and vascular endothelial growth factor/vascular permeability factor (VEGF) (18).

VEGF is a family of secreted polypeptides that stimulate vascular endothelial cell proliferation and monocyte migration in vitro $(19,20)$ and promote vascular permeability and angiogenesis in vivo (21-23). Unlike acidic and basic FGF, VEGF is an efficiently secreted glycoprotein (24) and an endothelial-selective mitogen $(19,23)$. Recently, VEGF mRNA was shown to be increased in the presumed hypoxic regions of human glioblastomas and in hypoxic rat tumor and skeletal muscle cell lines in vitro $(8,25)$. In separate experiments, neutralizing monoclonal antibodies to VEGF were reported to block tumor growth (26). These data make VEGF a likely candidate to mediate tumor angiogenesis (27). In addition, the finding that VEGF protein is present in the retina (28) raises the possibility that VEGF may be involved in ocular neovascularization.

We have found that an increase in the production of endothelial mitogenic activity by hRPE during hypoxia is due to the increased synthesis and secretion of VEGF. The induction of VEGF mRNA and protein, and the identity of the specific isoforms of VEGF produced during hypoxia are described. We also examine the effect of hypoxia on the regulation of bFGF, a potent endothelial cell mitogen produced by hRPE, to determine if the induction of VEGF during hypoxia is part of a general cellular response designed to increase angiogenic factor production. Lastly, we use a soluble high-affinity VEGF receptor (human $f l t-1$ ) as a competitive inhibitor of VEGF activity to determine the contribution of VEGF to the hypoxia-inducible endothelial mitogenic activity of hRPE. These studies support the hypothesis that hypoxia induces angiogenic activity in the eye and suggests that VEGF may participate in the ocular neovascular response associated with ischemia.

\section{MATERIALS AND METHODS}

\section{Human Retinal Pigment Epithelial Cell (hRPE) Culture}

hRPE cultures were established and propagated as previously described (18). Following trypsinization, hRPE were plated at 15,000 cells $/ \mathrm{cm}^{2}$ (sparse) and at $55,000 \mathrm{cells} / \mathrm{cm}^{2}$ (dense) into sixwell plastic dishes (Costar) in $10 \%$ fetal calf serum (FCS)/Dulbecco's modified Eagle's media (DMEM) and were allowed to attach and spread. 
One to 3 days later, sparsely plated cells were $25-50 \%$ confluent and high density cells were confluent. The media were changed and the cells were placed into sealed chambers (BillupsRothenberg) and exposed to either $5 \% \mathrm{CO}_{2} / 0 \%$ $\mathrm{O}_{2} / 95 \% \mathrm{~N}_{2}$ (hypoxia) or $5 \% \mathrm{CO}_{2} / 21 \% \mathrm{O}_{2} / 74 \%$ $\mathrm{N}_{2}$ (normoxia) for 6,12 , or $24 \mathrm{hr}$ at $37^{\circ} \mathrm{C}$. Purging the culture chambers with a $\mathrm{CO}_{2} / \mathrm{N}_{2}$ mixture has been previously shown to result in a $\mathrm{PO}_{2}$ of 14-18 (an oxygen concentration of $2 \%$ ) (5). Following incubation, the cells were scraped into lysis buffer for RNA isolation, or were processed as described below for biosynthetic labeling. Cells of parallel cultures were trypsinized and counted electronically. Each condition was prepared in triplicate, and the experiments were carried out at least three times with reproducible results.

\section{Bovine Capillary Endothelial Cell (BCE) DNA Synthesis and Proliferation Assays}

For DNA synthesis assays, media conditioned by hRPE for $24 \mathrm{hr}$ were collected, clarified by centrifugation and mixed with $5 \%$ heat-inactivated bovine calf serum/DMEM at a $40 / 60$ ratio $(\mathrm{v} / \mathrm{v})$ and assayed on BCE for DNA synthesis measurements as previously described (29). Proliferation assays were performed as described (30), with a single addition of sample media or growth factors $2 \mathrm{hr}$ after the cells are plated. Human recombinant VEGF ( $2 \mathrm{ng} / \mathrm{ml}$; provided by Genentech) and bFGF ( $1 \mathrm{ng} / \mathrm{ml}$; provided by Takeda Chemical Industries, Ltd., Osaka, Japan) were added directly to assay media ( $10 \%$ calf serum/ DMEM). Conditioned media (in serum-free DMEM) were collected from $20 \mathrm{hr}$ normoxic or hypoxic hRPE cultures, clarified and concentrated approximately 10 -fold by centrifugation in Centricon-10 (Amicon) microconcentrators and assayed at $75-100 \mu \mathrm{l} / \mathrm{ml}$ assay media. Soluble flt- 1 and CD4 receptors used in the neutralization studies were created as described (31) and were assayed for their effect on growth by addition to growth factor-supplemented media or conditioned media.

\section{Solid Phase bFGF Immunoassay and VEGF Fluoroimmunoassay}

Media conditioned for $24 \mathrm{hr}$ by hRPE grown under normoxic and hypoxic conditions were collected and clarified by centrifugation. Cells were then rinsed with phosphate buffered saline (PBS) containing heparin $(100 \mu \mathrm{g} / \mathrm{ml})$ to remove cell surface and extracellular matrix-associated
VEGF and bFGF and cell lysates were prepared as previously described. The media, heparin washes, and cell lysates were assayed for VEGF (32) and bFGF (33) levels using previously described immunoassays. Both immunoassays detect all known forms of the proteins. The limits of detection for the two assays were $0.2 \mathrm{ng} / \mathrm{ml}$ VEGF (34) and $5 \mathrm{pg} / \mathrm{ml}$ bFGF (MW. for calculations: VEGF $=42 \mathrm{kD}$ and $\mathrm{bFGF}=18 \mathrm{kD}$ ). Interassay variations were $13.7 \%$ for VEGF and 12.5 $\%$ for bFGF.

\section{Northern Blotting}

Total cellular RNA from hRPE cells was isolated using the guanidinium isothiocyanate/ $\mathrm{CsCl}$ method. Fifteen micrograms of RNA/sample were fractionated by denaturing electrophoresis, and capillary blotted to nylon (Hybond, Amersham). Prehybridization and hybridization were carried out in $6 \times$ SSPE, $5 \times$ Denhardt's, $50 \%$ formamide, $0.5 \%$ SDS and $100 \mu \mathrm{g} / \mathrm{ml}$ salmon sperm DNA. A 1.4-kb fragment of human bFGF (a gift of Dr. Stella Kourembanas, Children's Hospital, Boston, MA, U.S.A.) was labeled by asymmetric PCR. A 520-bp NcoI/BglII fragment of the human VEGF cDNA (a gift of Dr. Herbert Weich, Albert-Ludwigs Universitat, Freiburg, Germany) and a 280-bp fragment of bovine 28S ribosomal RNA (gift of Dr. Helene Sage, University of Washington, Seattle, WA) were labeled by random priming. 28S rRNA was used to confirm equal RNA loading. Quantification was carried out with a phosphoimager using Image Quant software (Molecular Dynamics) and 28S rRNA for normalization.

\section{Reverse Transcription-Polymerase Chain Reaction}

Total RNA (100 ng) was reverse transcribed using MMLV reverse transcriptase (Superscript; BRL). Approximately $1 \%$ of RT product was used for PCR amplification with primers flanking the human VEGF start and stop codons. Amplification was performed using standard GeneAmp PCR buffer with $200 \mu \mathrm{M}$ dNTP's, 50 pmol primers and 2.5 U Amplitaq (Perkin Elmer). The parameters for amplification were: $94^{\circ} \mathrm{C}, 3-\mathrm{min}$ initial denaturation; 30 cycles of $94^{\circ} \mathrm{C}, 45 \mathrm{sec} ; 55^{\circ} \mathrm{C}$, $1 \mathrm{~min} ; 72^{\circ} \mathrm{C}, 1 \mathrm{~min}$, and a $3 \mathrm{~min}$ final extension at $72^{\circ} \mathrm{C}$. Products were separated and visualized in ethidium bromide-stained agarose gels. Products were transferred to nylon for Southern blot analysis using a random prime labeled human VEGF cDNA, as described above. 


\section{Immunoprecipitation}

Human hRPE were grown under normoxic and hypoxic conditions for $24 \mathrm{hr}$ in the presence of DMEM $/ 1 \%$ FCS and $200 \mathrm{uCi} / \mathrm{ml}{ }^{35} \mathrm{~S}$-methionine/cysteine (New England Nuclear, Boston, MA) followed by immunoprecipitation of media and lysates. Briefly, the media were collected and cells were washed in PBS followed by PBS containing heparin (as described above). Lysates were prepared in lysis buffer containing $20 \mathrm{mM}$ Tris $\mathrm{pH} 8.0,200 \mathrm{mM} \mathrm{NaCl}, 1 \% \mathrm{NP}-40,0.1 \%$ CHAPS, $5 \mathrm{mM}$ EDTA, $1 \mu \mathrm{g} / \mathrm{ml}$ leupeptin, $1 \mu \mathrm{g} / \mathrm{ml}$ aprotonin, $0.5 \mu \mathrm{g} / \mathrm{ml}$ pepstatin, and $200 \mu \mathrm{g} / \mathrm{ml}$ heparin. Conditioned media and heparin washes were adjusted to the same concentration of lysis buffer using a $10 \times$ lysis buffer stock. Lysates, media, and heparin washes were normalized against equal protein and incubated with the appropriate antisera and nonimmune controls (all diluted in $50 \mu \mathrm{g} / \mathrm{ml}$ BSA to block nonspecific interactions). Rabbit polyclonal VEGF antiserum (gift of Dr. Dan Connolly, Monsanto Corporation, St. Louis, MO, U.S.A.), sheep polyclonal anti-human bFGF IgG (gift of Dr. Michael Klagsbrun, Children's Hospital, Boston, MA, U.S.A. (characterized in Ref. 35) and non-immune controls (rabbit serum for VEGF and sheep IgG for bFGF) were used. Immune complexes were isolated with protein A-agarose (Pierce Chemical Co., Rockford, IL, U.S.A.), which was preabsorbed with excess unlabeled hRPE lysate to block non-specific binding sites. Specificity of VEGF antisera was demonstrated by immunoprecipitation in the presence of $5 \mu \mathrm{g} / \mathrm{ml}$ unlabeled human recombinant VEGF. Bound immune complexes were eluted in SDS sample buffer with $100 \mathrm{mM}$ iodoacetamide, heated to $37^{\circ} \mathrm{C}$ for $5 \mathrm{~min}$, boiled, and analyzed by SDSPAGE and autoradiography.

\section{RESULTS}

To determine if hypoxia resulted in the increased production of endothelial growth factors by hRPE, media conditioned by hRPE grown in an hypoxic environment were assayed for their ability to stimulate DNA synthesis by bovine capillary endothelial cells (Fig. 1). Human RPE exposed to hypoxia for $24 \mathrm{hr}$ retained a normal morphology (compare Fig. lb and c) but proliferated more slowly than normoxic cells. The effect was reversible as hRPE returned to normoxia resumed proliferation at a normal rate (data not shown). Media conditioned by hypoxic hRPE in- creased DNA synthesis of capillary endothelial cells 2 -fold above control nonconditioned media. In contrast, media from hRPE grown for $24 \mathrm{hr}$ in normoxia did not contain any significant stimulatory activity.

\section{Northern Analysis of bFGF and VEGF Expression by hRPE in Response to Hypoxia}

These initial data prompted us to investigate the regulation of specific endothelial cell growth factors. hRPE have been reported to make bFGF (15), and we had demonstrated that the hRPE synthesize VEGF (18). Changes in the steadystate levels of VEGF and bFGF mRNA were examined following 6,12 , and $24 \mathrm{hr}$ of hypoxia (Fig. 2). Whereas VEGF mRNA was barely detectable in cells grown under normoxic conditions, there was a marked increase in VEGF transcripts $(3.7$ and $4.0 \mathrm{~kb}$ ) following $6 \mathrm{hr}$ exposure to hypoxia and even greater elevation in the level of VEGF mRNA after $24 \mathrm{hr}$ of hypoxia.

All four reported bFGF transcripts $(7.0,3.7$, 2.2 , and $1.2 \mathrm{~kb}$ ) were observed in hRPE grown under both normoxic and hypoxic conditions. There was little change after $6 \mathrm{hr}$ of hypoxia. However, in contrast to the results obtained with VEGF, there was a consistent reduction in bFGF mRNA after 12 and $24 \mathrm{hr}$ of growth in the lower oxygen tension, to approximately $30 \%$ of the levels in the normoxic control cells. The levels of all of the bFGF transcripts were reduced by exposure of the hRPE to hypoxia. Equal loading of RNA was demonstrated by hybridization with a probe to the $28 \mathrm{~S}$ rRNA.

Of the four variants of VEGF created by alternative splicing, VEGF ${ }_{121}$ and $\mathrm{VEGF}_{165}$ (number indicates amino acids in mature protein) have low affinity for heparin and are readily secreted whereas VEGF $_{189}$ and VEGF $_{206}$ display an increased heparin affinity and association with the cell surface, presumably due to a highly basic 24 amino acid insert (36). To determine which of the splice variants were being produced by the hRPE, total RNA from hRPE grown for 12 $\mathrm{hr}$ under normoxia and hypoxia was subjected to RT-PCR and Southern blot analysis. The predominant band of approximately $440 \mathrm{bp}$ corresponds to the predicted size of VEGF 121 amplification products. In addition, a faint signal is present at approximately $590 \mathrm{bp}$ and corresponds to the predicted size of the VEGF VE5 $_{165}$ product (Fig. 3a). The identity of these amplified products was confirmed by Southern blot analy- 


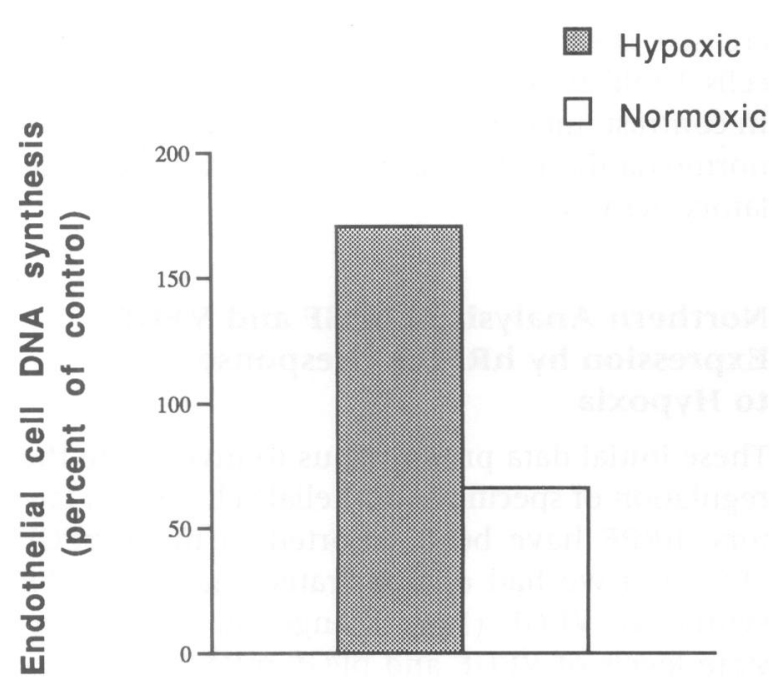

FIG. 1. (a) Effect of media conditioned by hRPE grown under normoxic and hypoxic conditions on DNA synthesis by bovine capillary endothelial cells

Bovine capillary endothelial cells were plated at $10,000 / 2.1 \mathrm{~cm}$ well. Media conditioned for $24 \mathrm{hr}$ by hRPE grown under hypoxia (black bar) or normoxia (empty bar) were added and DNA synthesis assessed. Results are expressed as percentage of unconditioned control media. Phase micrographs of hRPE prior to (b) and following (c) $24 \mathrm{hr}$ of hypoxia.

sis of products from 25 cycles and 30 cycles of amplification (Fig. 3b).

\section{Synthesis of bFGF and VEGF Protein by hRPE in Response to Hypoxia}

Elevated levels of mRNA do not always lead to increased protein production; therefore, we examined the effects of hypoxia on the synthesis of bFGF and VEGF protein by hRPE. Metabolic labeling studies were performed on hRPE grown for $24 \mathrm{hr}$ under normoxic and hypoxic conditions (Fig. 4). Analysis of media conditioned by the cells revealed low levels of VEGF synthesized and secreted by normoxic hRPE (conditioned media, Lane 2). Markedly increased (greater than 10-fold) levels of newly synthesized VEGF were present in the media following $24 \mathrm{hr}$ of hypoxia (conditioned media, Lane 4). The upper band most likely represents the glycosylated VEGF $_{165}$, the lower band the nonglycosylated VEGF $_{121}$ and the middle band a combination of the nonglycosylated 165 amino acid form together with the glycosylated 121 amino acid form (37) . Low levels of VEGF were present in b

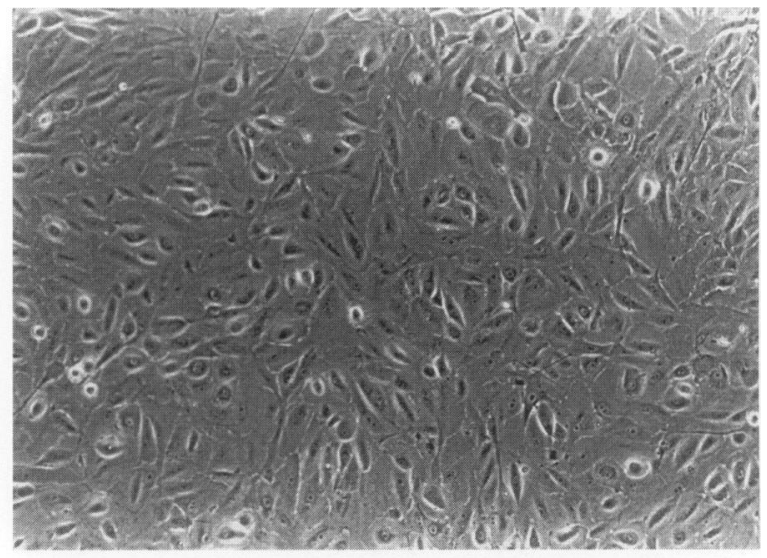

C
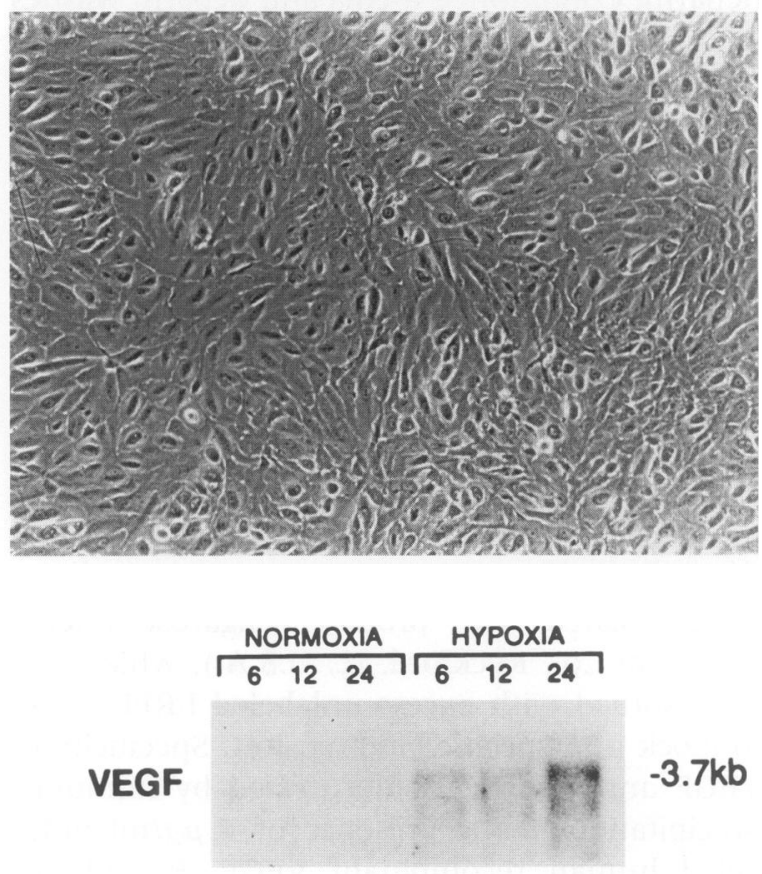

$-3.7 \mathrm{~kb}$

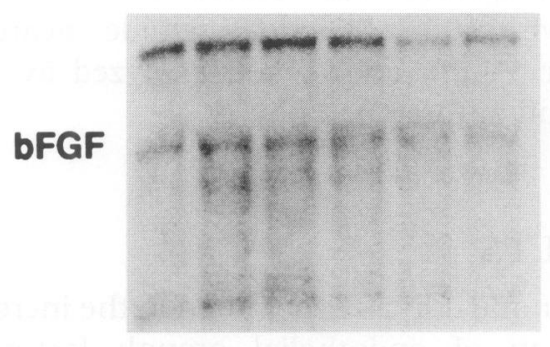

$-7 \mathrm{~kb}$

$-3.7 k b$

$-2.2 k b$

$-1.4 \mathrm{~kb}$

\section{5 probe}

FIG. 2. Effect of hypoxia on steady state levels of VEGF and bFGF MRNA

hRPE were plated at 15,000 cells $/ \mathrm{cm}^{2}$ and allowed to grow to confluence. Total RNA was isolated from hRPE grown under normoxic or hypoxic conditions for 6,12 , and $24 \mathrm{hr}$. After probing for VEGF (a) the same blot was stripped and used for analysis of bFGF (b) and 28S rRNA (c). 


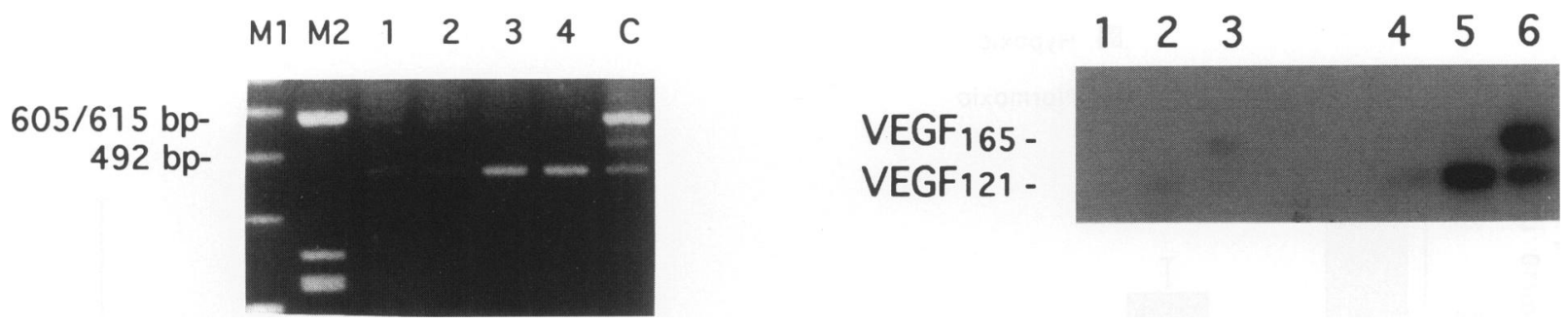

FIG. 3. RT-PCR and Southern blot analysis of mRNA from normoxic and hypoxic hRPE

(a) hRPE were cultured as described in the legend of Fig. 2. RT-PCR (35 cycles) of total RNA from normoxic (Lanes 1 and 2) and hypoxic (Lanes 3 and 4) hRPE, visualized by ethidium bromide-stained agarose gel analysis. M1, 123 bp ladder, M2 HaeIII digest of phi X174; C, is a control using monkey retina mRNA, which contains both VEGF121 and VEGF165 splice variants. (b) Southern blot analysis of RT-PCR products using a hVEGF cDNA probe. Products from cycles 25 and 30 were analyzed for normoxic cDNA (Lanes 1 and 4), hypoxic cDNA (lanes 2 and 5) and control monkey retina cDNA's (Lanes 3 and 6). Blank cDNA controls yielded no detectable products (data not shown).

cells grown under normoxic conditions (cell lysate, Lane 2). However, in spite of the obviously enhanced synthesis, VEGF was barely detectable in lysates of cells grown in an hypoxic environment (cell lysate, Lane 4). This is not an unexpected result since VEGF is a rapidly secreted glycoprotein with a cellular half-retention time of $3 \mathrm{~min}(24)$. The specificity of the antisera was demonstrated in controls in which an excess of unlabeled human recombinant VEGF blocked the immunoprecipitation products (Fig. 4, upper right panel)

In contrast to VEGF, bFGF was undetectable

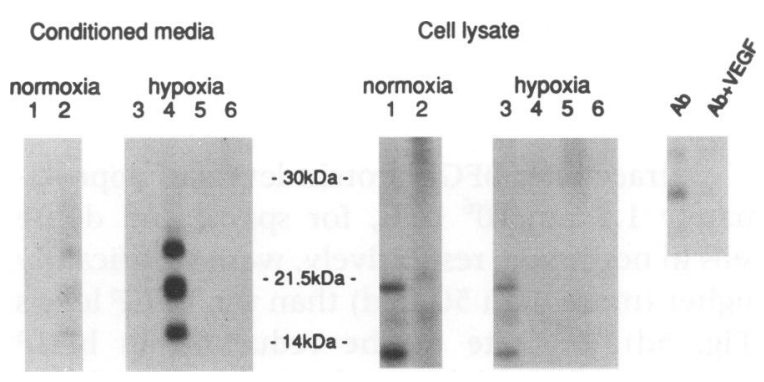

FIG. 4. Effect of hypoxia on the synthesis of VEGF and bFGF

hRPE were cultured as described in the legend of Fig. 2. At confluence the hRPE were grown for 24 $\mathrm{hr}$ in normoxic and hypoxic environments and ${ }^{35} \mathrm{~S}$-labeled proteins were immunoprecipitated from conditioned media and cell lysates using sheep antihuman recombinant-bFGF IgG (Lanes 1 and 3) or rabbit antisera to VEGF (Lanes 2 and 4). Controls included sheep non-immune IgG (Lane 5) and control nonimmune rabbit serum (Lane 6). Specificity of the VEGF antisera is demonstrated by competition for ${ }^{35} \mathrm{~S}$-VEGF in the conditioned media (upper right panel). in the conditioned media of hRPE grown in normoxia (Fig. 4 conditioned media, lane 1) or hypoxia (conditioned media, Lane 3 ). Newly synthesized $18 \mathrm{kD}$ bFGF was present at a significant level in the lysates of hRPE in normoxia (cell lysate, Lane 1). Biosynthetically labeled bFGF was also present in the lysates of cells grown under hypoxia (cell lysate, Lane 3), but the levels appeared to be slightly decreased, paralleling the decrease in the levels of mRNA. The $12 \mathrm{kD}$ species most likely represents a common, stable degradation product of bFGF. Nonspecific immunoreactivity was minimal (Lanes 5 and 6 for conditioned media and cell lysate).

\section{Alterations in bFGF and VEGF Protein Levels as a Result of Hypoxia}

The steady-state levels of VEGF and bFGF protein in cultures of hRPE grown under normoxic and hypoxic environments were quantified using solid phase immunoassays. Cell lysates, conditioned media, and heparin-PBS washes were collected from cultures grown for $24 \mathrm{hr}$ in normoxia or hypoxia. To ensure that induction of VEGF was not dependent on cell density, sparse and dense cell cultures were examined. Soluble heparin $(100 \mu \mathrm{g} / \mathrm{ml}$ PBS) was used to displace VEGF and bFGF bound to heparin-like molecules on the cell surface or in extracellular matrix.

Consistent with the results of the biosynthetic labeling studies, levels of VEGF in media of hypoxic cells were increased up to 4 -fold above normoxic cells $(p<0.002$ for both sparse and dense cultures) (Fig. 5a). Intracellular levels of VEGF in hRPE grown under normoxic conditions measured 0.02 and $0.04 \mathrm{pm} / 10^{6}$ cells for sparse and dense cells, respectively, and in- 
a

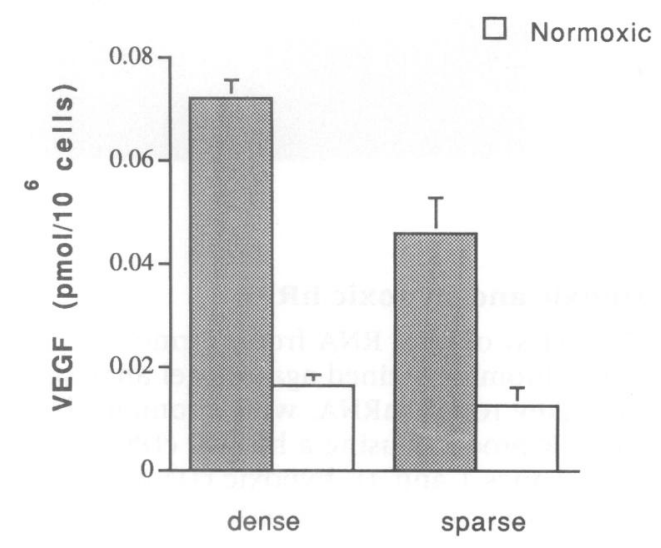

C

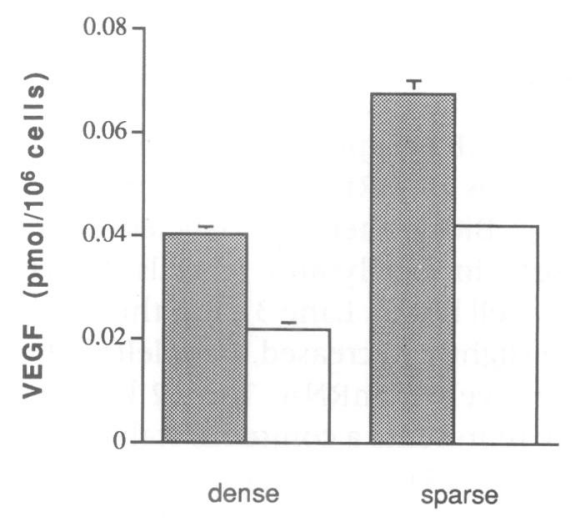

b

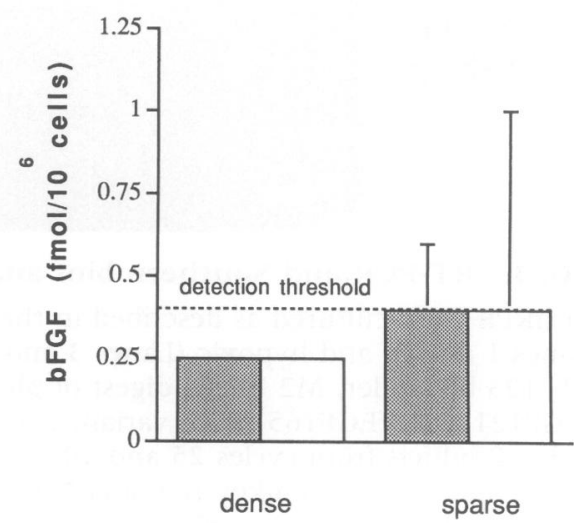

d

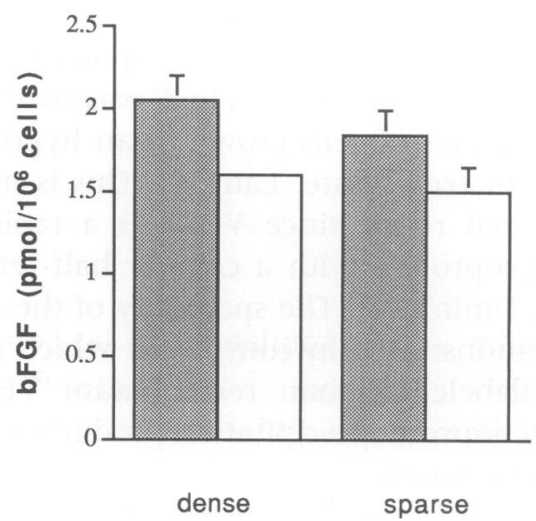

FIG. 5. Effect of hypoxia on steady-state VEGF and bFGF in hRPE

Conditioned media levels of (a) VEGF and (b) bFGF and cell lysates levels of (c) VEGF and (d) bFGF in sparse and confluent culture of hRPE were quantified by immunoassay. Open bars indicate cells grown under normoxia and black bars indicate hypoxic exposure. Levels of growth factor were normalized to cell number obtained from parallel cultures and are expressed as $\mathrm{pm} / 10^{6}$ cells \pm SEM.

creased by as much as $80 \%$ in cells grown under hypoxia for $24 \mathrm{hr}(p<0.0001$ for both sparse and dense cultures) (Fig. 5c). Although the absolute levels of VEGF differed between sparse and dense hRPE, the trend for increased protein in cells exposed to hypoxia was consistent. The concentration of VEGF in the conditioned media was above that required to maximally stimulate vascular endothelial cell proliferation in vitro (19). No VEGF was detected in the heparin-PBS washes, suggesting the presence of VEGF isoform(s) with lower heparin affinity (data not shown). This observation is consistent with the results of the RT-PCR analysis and immunoprecipitation studies, which indicate the synthesis of the 121 and 165 amino acid forms of VEGF, known to have relatively low affinity for cell surface heparan sulfate proteoglycans.
Intracellular bFGF protein levels of approximately $1.5 \mathrm{pm} / 10^{6}$ cells, for sparse and dense cells in normoxia, respectively, were significantly higher (more than 50-fold) than the VEGF levels (Fig. 5d). In spite of the reduction in bFGF mRNA levels and biosynthetic labeling, bFGF protein levels were not decreased $(p=0.007$ for dense cultures and $p=0.005$ for sparse cultures). These results suggest a role for the control of bFGF protein stability in the maintenance of steady state proteins levels. In agreement with the biosynthetic labeling analysis, no bFGF was detected in the media (Fig. 5b) or heparin washes (data not shown) of hRPE grown under the normoxia or hypoxia for $24 \mathrm{hr}$. However, bFGF was increased over 5 -fold in the media and heparin washes following $48 \mathrm{hr}$ of hypoxia (data not shown), a time when many of the cells were 
necrotic and detached from the substrate, and the adherent cells were vacuolated and retracted. Unlike the findings for VEGF, cell density did not appear to influence the absolute levels of bFGF.

\section{VEGF's Role as an Hypoxia-Induced Mitogen}

To determine if VEGF is a component of the hypoxia-induced mitogenic activity in hRPE conditioned media, a modified high-affinity VEGF receptor was used to neutralize VEGF activity. The receptor is a chimeric protein, containing the extracellular domain of the flt- 1 receptor tyrosine kinase fused to the Fc portion of human IgG heavy chain. The 758 amino acids of extracellular domain of flt- 1 were fused to the coding sequence (216-443) of IgG-1 heavy chain clone. The addition of the $\mathrm{Fc}$ region was engineered to increase the half-life of the soluble receptor, while not affecting the ligand binding capacity (31). These molecules, as well as naturally occurring soluble VEGF receptors, neutralize VEGF bioactivity (Park et al., manuscript submitted) (38). The flt-1/Fc chimera, and a control CD4/FC chimera were first tested for their ability to neutralize VEGF stimulated capillary endothelial cell growth (Fig. 6a). Soluble flt-1/Fc blocked cell proliferation by VEGF in a dose-dependent manner. At $300 \mathrm{ng} / \mathrm{ml}$, soluble flt-1/Fc completely inhibited VEGF activity, whereas a 5-fold excess of soluble flt-1/Fc $(60 \mathrm{ng} / \mathrm{ml})$ was approximately $50 \%$ as effective. At $12 \mathrm{ng} / \mathrm{ml}$, the soluble receptor had no apparent effect. No neutralization was observed with similar ratios of the CD4/Fc soluble receptor, and the highest doses of $f l t-1 / \mathrm{Fc}$ and $\mathrm{CD} 4 / \mathrm{Fc}$ had no effect on baseline unstimulated endothelial cell growth.

As we initially observed (Fig. 1), conditioned media from hRPE grown in hypoxia stimulated endothelial cell growth when compared to unconditioned media or media conditioned in normoxia $(p=0.008)$ (Fig. $6 \mathrm{~b})$. The addition of 200 $\mathrm{ng} / \mathrm{ml}$ of $\mathrm{CD} 4 / \mathrm{Fc}$ had no significant effect on endothelial cell growth in normoxic or hypoxic conditioned media, whereas the addition of 200 $\mathrm{ng} / \mathrm{ml}$ of $f l t-1 / \mathrm{Fc}$ completely abolished the hypoxia-induced mitogenic activity in hRPE conditioned media $(p=0.003)$. As with the CD4/FC, flt-1/Fc had no effect on the growth of endothelial cells in media conditioned by hRPE in normoxia. The specificity of the $f l t-1 / F c$ receptor is evidenced by the inability of soluble flt-1/Fc to inhibit bFGF (l $\mathrm{ng} / \mathrm{ml})$-stimulated endothelial cell growth, while completely neutralizing VEGF (2 $\mathrm{ng} / \mathrm{ml})$-stimulated growth.

\section{DISCUSSON}

Strong correlative evidence points to a role for hypoxia as a key regulator of angiogenesis. Hypoxia is a well-documented component of a number of processes characterized by angiogenesis including wound healing, tumor vascularization, diabetic retinopathy and ischemic heart disease. Observations from in vivo models from our lab (1) and others $(8,25,39)$ strongly implicate VEGF in these process.

hRPE are a relevant choice of cells for the study of hypoxia-regulated angiogenic factors. They can be grown under hypoxic conditions for $24 \mathrm{hr}$ without any apparent adverse effects. hRPE in vitro have been reported to synthesize at least four known angiogenic factors including VEGF (18), bFGF (15), interleukin-8 (16), and aFGF (17), and we have found that their exposure to hypoxia leads to an increase in the levels of secreted angiogenic factors. In addition, the pigment epithelium in vivo has been implicated in the maintenance of retinal and choroidal integrity $(40,41)$ and has been postulated to participate in a variety of fibrovascular pathologies. Finally, RPE isolated from postmortem eyes contain significant levels of VEGF (18) and in situ hybridization of VEGF in untreated nonhuman primate retinas indicate that RPE constitutively synthesize VEGF (manuscript in preparation). Information on the regulation of angiogenic factors by the human hRPE may be relevant not only to the pathogenesis of a number of retinopathies but also to an understanding of retinal development.

Our data demonstrate that two physiologically relevant angiogenic factors, VEGF and bFGF, are differentially regulated by hypoxia. Northern analysis of hRPE grown for $24 \mathrm{hr}$ in an hypoxic environment revealed a substantial decrease in bFGF mRNA that was paralleled by a reduction in the synthesis of cell-associated bFGF. This is in contrast to what has been reported for bFGF in experimental models of injury. Basic FGF protein has been shown to be dramatically elevated following chemical injury to cardiac tissue (42), mechanical injury to the brain (43), and crush injury to the optic nerve (44). Furthermore, hRPE that are "activated" by inflammatory cytokines synthesize and secrete IL-8, a potent angiogenic molecule and endothelial mitogen. As with bFGF, we could detect no increase in IL-8 mRNA after $24 \mathrm{hr}$ of hypoxia (APA, DTS, and Victor M. Elner; unpublished observation). Thus, the response of cells to hy- 

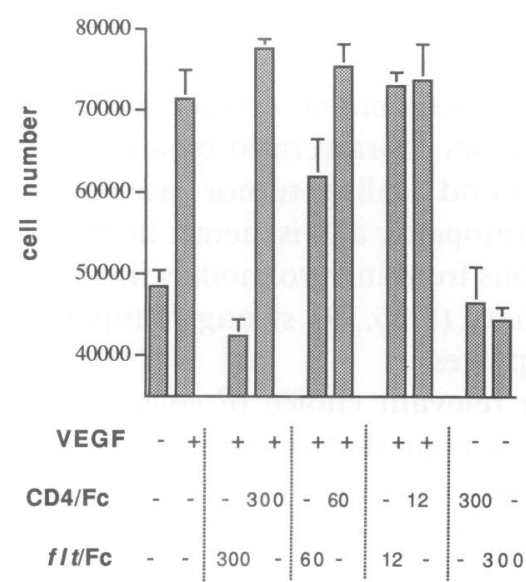

b

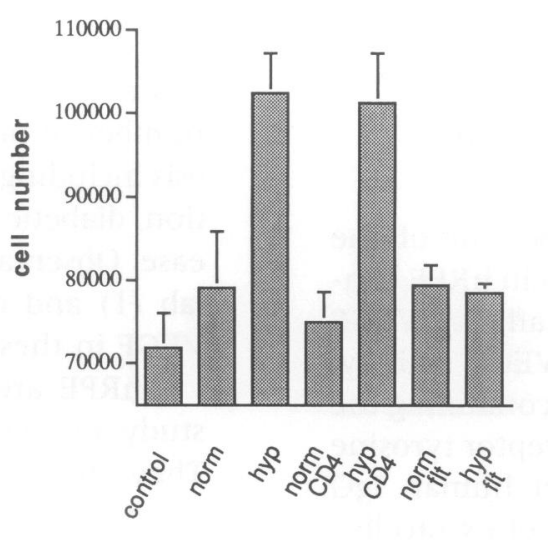

c

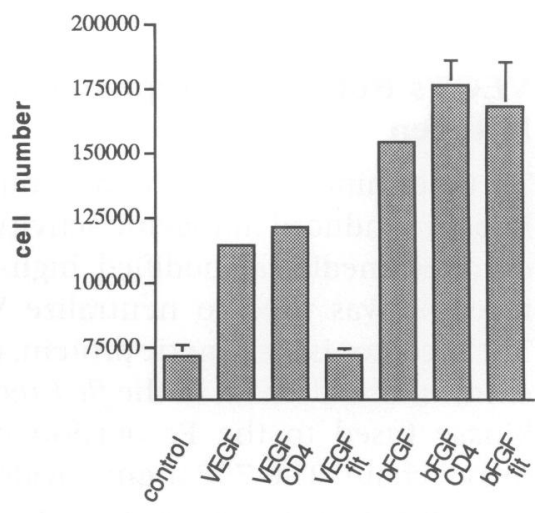

FIG. 6. Role of VEGF as a hypoxia-inducible mitogen

All results expressed as the mean cell number of triplicate wells \pm SD. Note $y$-axis does not originate at zero. (a) flt-1/Fc and CD4/Fc soluble receptors (in $\mathrm{ng} / \mathrm{ml}$ ) were tested for the ability to neutralize VEGF $(2 \mathrm{ng} / \mathrm{ml}$ ) stimulated endothelial cell proliferation. (b) Growth of endothelial cells in conditioned media from normoxia and hypoxia cultured hRPE, and in conditioned media plus flt-1/Fc or CD4/Fc soluble receptors $(200 \mathrm{ng} / \mathrm{ml})$. (c) Soluble receptor $(200 \mathrm{ng} / \mathrm{ml})$ effects on VEGF $(2 \mathrm{ng} / \mathrm{ml})$ and bFGF $(1 \mathrm{ng} / \mathrm{ml})$ stimulated growth of endothelial cells.

poxia differs markedly from their response to other forms of cellular stress. Densely growing cells produced more VEGF per cell than sparse cells. Although the relevance of this observation is not clear, it may reflect the effect of autocrine growth factors on VEGF expression. RPE cells make a number of growth factors including TGF- $\beta$, which have been shown to increase the expression of VEGF (45).

Steady-state levels of VEGF mRNA levels were markedly increased after $6 \mathrm{hr}$ of hypoxia, and this increase was maintained for up to $24 \mathrm{hr}$. The elevation in VEGF mRNA was associated with a significant increase in VEGF protein synthesis and secretion, indicating that hypoxia specifically induces increased VEGF production and secretion. Of the four potential splice variants, $\mathrm{VEGF}_{189}$ and $\mathrm{VEGF}_{206}$ display significant heparin affinity and are not found in media conditioned by cells expressing these two forms, whereas $\mathrm{VEGF}_{165}$ and $\mathrm{VEGF}_{121}$ have relatively low heparin affinity and are secreted and soluble (19). The results of RT-PCR analysis indicate the production of $\mathrm{VEGF}_{121}$ and to a lesser extent $\mathrm{VEGF}_{165}$ isoforms. These findings are corroborated by biosynthetic labeling studies which reveal the production of soluble proteins of the appropriate molecular size, and by ELISA analysis which indicates that a majority of the VEGF is secreted.

Considering the number of mitogens that are known to be synthesized by hRPE $(15,16,46,47)$, it was surprising that VEGF bioactivity was the only endothelial mitogen detectable in media conditioned by the hypoxic hRPE. These results are consistent with VEGF playing a major role in ischemia-associated neovascularization. In support of these in vitro data, we have found that aqueous fluid collected from monkeys with experimental iris neovascularization secondary to retinal ischemia, had no detectable increase in bFGF (unpublished observations, J. W. Miller and A. P. Adamis) yet had consistently elevated levels of VEGF (1). Although these studies draw attention to VEGF as a candidate factor for ocular neovascular disease, we believe that bFGF may also contribute to vessel growth associated with various types of tissue damage or wounding. This postulate draws support from animal and culture studies demonstrating that mechanical stress results in transient, nonlethal disruptions in cell membranes which lead to the passive release of bFGF $(48,49)$. We find that $48 \mathrm{hr}$ of hypoxia, which results in a dramatic decrease in cell viability and cell membrane integrity, leads to a substantial increase in the release of bFGF into the media of hRPE as detected by immunoassay.

Our in vitro findings are complemented by a growing number of in vivo studies which implicate VEGF in normal as well as pathologic neovascularization. We have documented a tempo- 
ral and spatial correlation between ischemiainduced neovascularization in the eye and VEGF mRNA and protein levels (1). Consistent with these observations, we have found that vitreous from human eyes with proliferative diabetic retinopathy contain significantly elevated levels of VEGF (50). In situ hybridization of several human tumors revealed upregulation of VEGF mRNA in tumor cells bordering necrotic tumor tissue whereas mRNA for its receptor (flt-1) was confined to the endothelium $(8,25,51,52)$. Similarly, bFGF has been detected in the vitreous of human eyes with active neovascularization (53). Elevated bFGF was been measured in the urine of individuals with bladder tumors (54) and in the serum of some patients with breast tumors (H. Watanabe, H., et al., manuscript submitted). Our results suggest that while ischemic (and therefore hypoxic) tissues upregulate the synthesis of VEGF, necrotic tissue might passively leak bFGF. As VEGF and bFGF have been shown to act synergistically (55), simultaneous local increases in these two angiogenic factors may lead to a more exuberant neovascular response.

\section{ACKNOWLEDGMENTS}

This work was supported by funds from EY05985 (PAD), CA45548 (PAD), EY00325 (APA), and Beth Israel Hospital Pathology Foundation, Inc. (KTY, TKY).

We thank Donald Senger for the anti-VEGF antisera used in the immunoassay, Ying Zhou for the excellent technical assistance, Dr. Harold Dvorak for his helpful comments, Dr. Stella Kourembanas for generously sharing her insights regarding hypoxic regulation of bFGF gene expression, and Sandra R. Smith for her assistance in performing the proliferation assays.

\section{REFERENCES}

1. Miller JW, Adamis AP, Shima DT, D'Amore PA, Moulton RS, O'Reilly MS, et al. (1994) Vascular permeability factor/vascular endothelial cell growth factor is temporally and spatially correlated with ocular angiogenesis in a primate model. Am. J. Pathol. 145: 574584.

2. Adair TH, Gay WJ, Montani JP. (1990) Growth regulation of vascular system: evidence for a metabolic hypothesis. Am. J. Physiol. 259: R1-R12.
3. Heacock CS, Sutherland RM. (1990) Enhanced synthesis of stress proteins by hypoxia and relation to altered cell growth and metabolism. Br. J. Cancer 62: 217-225.

4. Kourembanas S, Marsden PA, McQuillan LP, Faller, DV. (1991) Hypoxia induced endothelin gene expression and secretion in cultured human endothelium. J. Clin. Invest. 88: 1054-1057.

5. Kourembanas S, Hannan RL, Faller, DV. (1990) Oxygen tension regulates the expression of platelet-derived growth factor-B chain in human endothelial cells. J. Clin. Invest. 86: 670-764.

6. Goldberg MA, Dunning SP, Bunn HF. (1988) Regulation of the erythropoietin gene: Evidence that the oxygen sensor is a heme protein. Science 242: 1412-1414.

7. Knighton DR, Hunt TK, Scheuenstahl H, Halliday BJ, Werb Z, Banda MJ. (1983) Oxygen tension regulates the expression of angiogenesis factor by macrophages. Science 221: 1283-1285.

8. Shweiki D, Itin A, Soffer D, Keshet E. (1992) Vascular endothelial growth factor induced by hypoxia may mediate hypoxia-initiated angiogenesis. Nature 359: 843-845.

9. Shreeniwas R, Ogawa S, Cozzolino F, Torcia G, Braunstein N, Butura C, et al. (1991) Macrovascular and microvascular endothelium during long-term hypoxia: Alterations in cell growth, monolayer permeability, and cell surface coagulant properties. $J$. Cell. Phys. 146: 8-17.

10. Michaelson IC. (1948) The mode of development of the vascular system of the retina with some observations on its significance for certain retinal diseases. Trans. Ophthalmol. Soc. U.K. 68: 137-180.

11. Ashton N, Ward B, Serpell G. (1954) Effect of oxygen on developing retinal vessels with particular reference to the problem of retrolental fibroplasia. Br. J. Ophthalmol. 38: 397432.

12. McAvoy JW, Chamberlain CG. (1990) Growth factors in the eye. Prog. Growth Factor Res. 2: 29-43.

13. Sarks SH. (1980) Drusen and their relationship to senile macular degeneration. Aust. J. Ophthalmol. 8: 117-130.

14. Seaton AD, Turner JE. (1992) RPE transplants stabilize retinal vasculature and prevent neovascularization in the RCS rat. Invest. Ophthal. Vis. Sci. 33: 83-91.

15. Sternfeld MD, Robertson JE, Shipley GD, 
Tsai J, Rosenbaum JT. (1989) Cultured human retinal pigment epithelial cells express basic fibroblast growth factor and its receptor. Curr. Eye Res. 8: 1029-1037.

16. Elner VM, Strieter RM, Elner SG, Baggioline M, Lindley I, Kunkel SL. (1990) Neutrophil chemotactic factor (IL-8) gene expression by cytokine-treated retinal pigment epithelial cells. Am. J. Pathol. 136: 745750 .

17. Kitaoka $\mathrm{T}$, Bost LM, Ishigooka $\mathrm{H}$, Aotaki-Keen AE, Hjemeland L. (1993) Increasing cell density down-regulates the expression of aFGF by human RPE cells in vitro. Curr. Eye Res. 12: 993-999.

18. Adamis AP, Shima DT, Yeo K-T, Yeo T-K, Brown LF, Berse B, et al. (1993) Synthesis and secretion of vascular permeability factor/vascular endothelial growth factor by human retinal pigment epithelial cells. Biochem. Biophys. Res. Commun. 193: 631-638.

19. Ferrara N, Houck KA, Jakeman LB, Winer J, Leung, DW. (1991) The vascular endothelial growth factor family of polypeptides. J. Cell. Biochem. 47: 211-218.

20. Clauss $M$, Gerlach $M$, Gerlach $H$, Brett J, Want F, Familletti PC, et al. (1990) Vascular permeability factor: A tumor-derived polypeptide that induces endothelial cell and monocyte procoagulant activity, and promotes monocyte migration. J. Exp. Med. 172: 1535-1545.

21. Senger DR, Galli SJ, Dvorak AM, Peruzzi CA, Harvey VS, Dvorak HF. (1983) Tumor cells secrete a vascular permeability factor that promotes accumulation of ascites fluid. Science 219: 983-985.

22. Keck PJ, Hauser SD, Krivi G, Sanzo K, Warren T, Feder J, et al. (1989) Vascular permeability factor, an endothelial cell mitogen related to PDGF. Science 246: 1309-1312.

23. Leung DW, Cachianes G, Kuang WJ, Goeddel DV, Ferrara, N. (1989) Vascular endothelial growth factor is a secreted angiogenic mitogen. Science 246: 1306-1309.

24. Yeo T-K, Senger DR, Dvorak HF, Freter L, Yeo, K-T. (1991) Glycosylation is essential for efficient secretion but not for permeability-enhabcing activity of vascular permeability factor (vascular endothelial growth factor). Biochem. Biophys. Res. Commun. 179: 1568-1575.

25. Plate KH, Breier G, Weich HA, Risau, W. (1992) Vascular endothelial growth factor is a potential tumour angiogenesis factor in human gliomas in vivo. Nature 359: 845848.

26. Kim KJ, Li B, Winer J, Armanini M, Gillett $\mathrm{N}$, Phillips HS, et al. (1993) Inhibition of vascular endothelial growth factor-induced angiogenesis supprresses tumor growth in vivo. Nature 362: 841-844.

27. Klagsbrun M, Soker, S. (1994) VEGF/VPF: The angiogenesis factor found? Curr. Biol. 3: 699-702.

28. McGookin ED, Stopa EG, Kuo-LeBlanc V, Baird A, Gonzales A-M, Hanneken A, et al. (1992) Vascular endothelial cell growth factor (VEGF) has a different distribution than basic fibroblast growth factor (bFGF) in the adult human retina. Invest. Ophthalmol. Vis. Sci. 15: 821a.

29. Shing Y, Folkman J, Sullivan R, Butterfield C, Murray J, Klagsbrun, M. (1984) Heparin affinity: Purification of a tumor-derived capillary endothelial cell growth factor. Science 223: 1296-1298.

30. Ferrara N, Leung DW, Cachanes G, Winer J, Henzel, WJ. (1991) Purification and cloning of vacular endothelial growth factor secreted by pituitary folliculostellate cells. Meth. Enzymol. 198: 391-405.

31. Park JE, Chen HH, Winer J, Houck KA, Ferrara N. (1994) Placenta growth factor. J. Biol. Chem. 269: 2564-2565.

32. Yeo K-T, Sioussat TM, Faix JD, Senger DR, Yeo, T-K. (1992) Development of time-resolved immunofluorometric assay of vascular permeability factor. Clin. Chem. 38: 71-75.

33. Watanabe H, Hori A, Seno M, Kozai Y, Igarishi K, Ichimori Y, et al. (1991) A sensitive enzyme immunoassay for human basic fibroblast growth factor. Biochem. Biophys. Res. Comm. 175: 229-235.

34. Yeo KT, Wang HH, Nagy JA, Sioussat TM, Ledbetter SR, Hoogewerf AJ, et al. (1993) Vascular permeability factor (Vascular endothelial growth factor) in guinea pig and human tumor and inflammatory effusions. Cancer Res. 53: 2912-2918.

35. Kandel J Bossy-Wetzel, E Radvany, F Klagsbrun, M Folkman, J Hanahan, D. (1991) Neovascularization is associated with a switch to the export of bFGF in the multistep development of fibrosarcoma. Cell 66: 10951104.

36. Ferrara N, Houck K, Jakeman L, Leung DW. (1992) Molecular and biological properties 
of the vascular endothelial growth factor family of proteins. Endocrine Rev. 13: 18-32.

37. Houck KA, Ferrara N, Winer J, Cachiane G. (1991) The vascular endothelial growth factor family: Identification of a 4th molecular species and characterization of alternative splicing of RNA. Mol. Endocrinol. 5: 18061814.

38. Kendall RL, Thomas KA. (1993) Inhibition of vascular endothelial cell growth factor activity by an endogenously encoded soluble receptor. Proc. Natl. Acad. Sci. U.S.A. 90: 10705-10709.

39. Dvorak HF, Sioussat TM, Brown LF, Berse B, Nagy JA, Sotrel A, et al. (1991) Distribution of vascular permeability factor (vascular endothelial growth factor) in tumors: Concentration in tumor blood vessels. J. Exp. Med. 174: $1275-1278$.

40. Korte GE, Repucci V, Henkind P. (1984) RPE destruction causes choriocapillary atrophy. Invest. Ophthalmol. Vis. Sci. 25: 1135-1145.

41. Li L, Turner JE. (1988) Inherited retinal dystrophy in the RCS rat: Prevention of photoreceptor degeneration by pigment epithelium cell transplantation. Exp. Eye Res. 47: 911-917.

42. Padua RR, Kardami E. (1993) Increased basic fibroblast growth factor (bFGF) accumulation and distinct patterns of localization in isoproterenol-induced cardiomyocyte injury. Growth Factors 8: 291-306.

43. Finklestein SP, Apostolides PJ, Caday CG, Prosser J, Philips MF, Klagsbrun M. (1988) Increased basic fibroblast growth factor (bFGF) immunoreactivity at the site of focal brain wounds. Brain Res. 460: 253-259.

44. Kostyk SK, D'Amore PA, Herman IM, Wagner JA. (1994) Optic nerve injury alters basic fibroblast growth factor localization in the retina and optic tract. J. Neurosci. 14: 1441-1449.

45. Pertovaara L, Kaipainen A, Mustonen T, Orpana A, Ferrara N, Saksela O, et al. (1994) Vascular endothelial growth factor is induced in response to transforming growth factor-beta in fibroblastic and epithelial cells. J. Biol. Chem. 269: 6271-6274.

46. Bost LM, Aotaki-Keen AE, Hjelmeland, LM.
(1992) Coexpression of FGF-5 and bFGF by the retinal pigment epithelium in vitro. Exp. Eye Res. 55: 727-734.

47. Campochiaro P. (1993) Cytokine production by retinal pigment epithelial cells (review). Int. Rev. Cyt. 146: 75-82.

48. McNeil PL. (1993) Cellular and molecular adaptations to injurious mechanical stress. Trends Cell Biol. 3: 302-307.

49. D'Amore PA. (1990) Modes of FGF release in vivo and in vitro. Cancer Met. Rev. 9: 227238.

50. Adamis AP, Miller JW, Bernal M-T, D'Amico DJ, Folkman J, Yeo T-K, et al. (1994) Elevated vascular permeability factor/Vascular endothelial growth factor levels in the vitreous of eyes with proliferative diabetic retinopathy. Am. J. Ophthalmol. 118: 445-450.

51. Brown LF, Berse B, Jackman RW, Tognazzi K, Manseau EJ, Senger DR, et al. (1993) Expression of vascular permeability factor (vascular endothelial growth factor) and its receptors in adenocarcinomas of the gastrointestinal tract. Cancer Res. 53: 47274735.

52. Brown LF, Berse B, Jackman RW, Tognazzi K, Manseau EJ, Dvorak HF, et al. (1993) Vascular permeability factor (vascular endothelial growth factor) and its receptors in kidney and bladder carcinomas. Am. J. Pathol. 143: 1255-1262.

53. Sivalingam A, Kenney J, Brown GC, Benson WE, Donoso, L. (1990) Basic fibroblast growth factor levels in the vitreous of patients with proliferative diabetic retinopathy. Arch. Ophthalmol. 108: 869-872.

54. Nguyen $M$, Watanabe $H$, Budson A, Richie J, Folkman J. (1993) Elevated levels of an angiogenic peptide, basic fibroblast growth factor, in urine of bladder cancer patients. $J$. Natl. Canc. Instit. 85: 241-242.

55. Pepper MS, Ferrara N, Orci L, Montesano R. (1992) Potent synergism between vascular endothelial growth factor and basic fibroblast growth factor in the induction of angiogenesis. Biochem. Biophys. Res. Commun. 189: 824-831. 